Our Nature (2011) 9: 107-111

\title{
Above-ground and Below-ground Biomass situation of Milke-Jaljale Rangeland at Different Altitudinal Gradient
}

\author{
D.K. Limbu ${ }^{1^{*}}$ and M. Koirala ${ }^{2}$ \\ ${ }^{1}$ Central Campus of Technology, T.U., Dharan, Nepal \\ ${ }^{2}$ Central Department of Environmental Science, T.U., Kirtipur, Nepal \\ ${ }^{*}$ E-mail:dilklimbu@yahoo.com
}

Received: 12.10.2011, Accepted: 28.11.2011

\begin{abstract}
Rangeland conservation has been increasingly interested for carbon reduction and mitigation of climate change, because of carbon storage. Thus, biomass of the rangeland remains pivotal regarding carbon sequestration on rangeland. Present study was conducted in high altitude rangeland at Jaljale $(4000 \mathrm{~m})$, Gorujure $(3500 \mathrm{~m})$ and Milke $(3000 \mathrm{~m})$ on September, 2010 with an objective to estimate rangeland biomass following the total harvesting method. Result revealed that biomass of high altitude rangeland has relatively high value (1.50 t/ha for both above ground biomass and 43.48 $\mathrm{t} / \mathrm{ha}$ for below ground biomass) compared to low altitude rangeland $(0.35 \mathrm{t} / \mathrm{ha}$ for above ground biomass and $16.93 \mathrm{t} / \mathrm{ha}$ for below ground biomass). Similarly, monocot plant density play crucial role for biomass contribution of rangeland.
\end{abstract}

Key words: Rangeland, biomass, carbon sequestration, high altitude.

\section{Introduction}

Rangelands represent the largest and most diverse land resource in the world. More than half of the world's land surface is grazed. Nearly 100 of the world's countries have at least one-half and 130 countries have at least one-third of their agricultural land area in grazing lands. Rangelands include 1.8 million hectors of land in Nepal, $12 \%$ of total land (LMP, 1993). Most of the rangelands fall under High Mountain $(50.3 \%)$ followed by high hill $(29 \%)$ and mid hill (16.7\%) (MOPE, 2002). High altitude rangelands are home to a unique assemblage of flora and fauna (Yonzon and Heinen, 1997). About 131 endemic plant species are found in the high altitude rangelands (Shrestha, 1997). It is repository of medicinal plants, world's most threatened and endemic species and provider of ecosystem goods and service to local people. The rangeland provides $36 \%$ of the total feed requirement for livestock in the country and livestock share $47.3 \%$ income of high altitude Nepalese household economy (Tulachan and Neupane, 1999). Over the centuries, the indigenous rangeland management system has been the base for sustained livestock production in Nepal. Despite the importance of local management of rangelands in bringing about economic betterment of the people of the northern areas of Nepal, the subject has remained largely unexplored (Rai and Thapa, 1993).

It is also a great pool of carbon. Rangelands have a large potential to sequester $\mathrm{C}$ because they occupy about half of the world's land area and store greater than $10 \%$ of terrestrial biomass $\mathrm{C}$ and 10 to $30 \%$ of global soil organic carbon (SOC) 
D.K. Limbu and M. Koirala/Our Nature (2011) 9:107-111

(Schlesinger, 1997; Scurlock and Hall, 1998). It is estimated that rangelands globally sequester $\mathrm{C}$ in soil at a rate of 0.5 Pg C yr-1 (Schlesinger, 1997; Scurlock and Hall, 1998). This implies that modest changes in $\mathrm{C}$ storage in rangeland ecosystems have the potential to modify the global $\mathrm{C}$ cycle and indirectly influence climate (Schimel et al., 1990; Ojima et al., 1993; Conant et al., 2001).

Because of global concern with climate change, it is expected that carbon markets will develop more rapidly and with deeper financial backing than other markets for ecosystem services. In the short-term, it is more likely that charismatic rangeland carbon assets that can contribute to purchaser's corporate public image would be of interest to the voluntary market.

The rangeland areas are highly degraded and overexploited. Owing to rangeland degradation its productivity and carbon pool is declining day by day. As a consequence, its negative impact is affecting the whole ecosystem. The main causes of degradation are over-grazing, poor management and low priority in government programme. Rangeland has high potentiality to uplift socio-economic condition of pastoralist; it can contribute to mitigate climate change through carbon sequestration in soil and help to promote tourism industries.

Plant biomass measurement is a fundamental procedure for grassland management and grassland field studies. It is important biophysical parameters of vegetation; vegetation biomass estimation not only is necessary for studying productivity, carbon circles, and nutrition allocation in terrestrial ecosystem but also important to the natural resources management since the amount of vegetation biomass directly influences human utilization patterns of surface vegetation and affects other biophysical parameters.

The objective of this paper is to compare above and below ground biomass of the plants of the three selected areas. The other objective is to determine whether the average biomass of the plants below the ground and above the ground of the selected sites can be considered statistically significant or not.

\section{Materials and methods \\ Study area}

Milke-Jaljale Mountain ridge lies as political border of Taplejung and Sankhuwasabha districts of eastern Nepal. Its geographical position is $27^{\circ} 17^{\prime} 35^{\prime \prime}$ to $27^{\circ} 30^{\prime} 28^{\prime \prime} \mathrm{N}$ latitude, $87^{\circ} 31^{\prime} 09^{\prime \prime}$ to $87^{\circ} 38$ '14' E longitude, extended from 3000 to $4500 \mathrm{msl}$ altitude. Its climatic condition is average temperature $10-15^{\circ} \mathrm{C}$ and average annual rainfall $1650 \mathrm{~mm}$. The area is under heavy human and livestock (yak, cattle, buffaloes, sheep and goats) pressures (Oli, 2002). It serves as habitat corridor between Makalu-Barun Conservation Area towards northwest and Kanchenjunga Conservation Area towards north-east, both of which touch the Qomolongma Biosphere Reserve in Tibet (Koirala, 2002).

The mountain ridges across MilkeJaljale are the natural niches for dozens of Rhododendron species. This is the capital of Rhododendron of Nepal and home to 27 species of Rhododendron.

\section{Experimental design}

The research work was carried out at three different altitudinal sites $(3000 \mathrm{msl}, 3500$ $\mathrm{msl}$ and $4000 \mathrm{msl}$ ) on September, 2010. At each altitudinal study site, five $30 \times 30 \mathrm{~cm}^{2}$ $15 \mathrm{~cm}$ deep quadrates were taken using 


\section{D.K. Limbu and M. Koirala/Our Nature (2011) 9:107-111}

completely randomized design, for the study. The biomass of the quadrates was estimated with total harvesting method. To estimate the above-ground biomass whole plants of the sampled quadrate were cut at ground level and packed separately in nylon bags and was made sun dry. Similarly, to estimate the below-ground biomass plants' root was excavated and washed with water jet in a $2 \mathrm{~mm}$ sieve. Washed plant roots were transferred to a spread plastic and impurities like sand and stones were removed. The sun-dried biomass was made oven dry at $70^{\circ} \mathrm{C}$ for $48 \mathrm{hr}$ till constant weight attained. Density was calculated by following Mention standard literature (Misra, 1968).

\section{Data analysis}

Initially, the descriptive statistics (mean, variance, range, standard error etc.) of the biomass were obtained for different sites. The variability in the biomass content in different sites were analyzed using one way ANOVA, since, the design of the experiment was completely randomized. Data were analyzed using SPSS 13. Above ground biomass and below ground biomass of the different sites were considered significant if $p$-values were less than or equal to $0.05 \quad(p \leq 0.05)$. In case of statistically significant result observed from ANOVA, a post hoc test, least significant difference (LSD) test was used for further identification of the significant mean difference.

\section{Result and discussion}

Biomass is depending upon major factors like temperature, moisture content, soil texture, photosynthesis, microbial activity, and available nutrients. Biomass productivity of grassland/rangeland has been reported variable on different places. In this study, both Above Ground Biomass (AGB) and Below Ground Biomass (BGB) depicted large spatial variations (Tab. 1). The range of the AGB was from $0.35 \mathrm{t} / \mathrm{ha}$ to $1.50 \mathrm{t} / \mathrm{ha}$ and similarly BGB were from $16.93 \mathrm{t} / \mathrm{ha}$ to $43.48 \mathrm{t} / \mathrm{ha}$. The largest AGB and BGB occurred in Jalajale rangeland at altitude $4000 \mathrm{msl}$. The high altitude rangeland showed high biomass productivity in both AGB and BGB. AGB and BGB of Jaljale at the altitude of 4000 $\mathrm{msl}$ were $1.02 \mathrm{t} / \mathrm{ha}$ and $41.62 \mathrm{t} / \mathrm{ha}$ respectively whereas $\mathrm{AGB}$ and $\mathrm{BGB}$ of Milke at the altitude of $3000 \mathrm{msl}$ were 0.62 $\mathrm{t} / \mathrm{ha}$ and $22.314 \mathrm{t} / \mathrm{ha}$ respectively. Both AGB and $\mathrm{BGB}$ of the studied rangelands showed increasing trend with altitudinal rise. A mean biomass of Suklaphant grassland at $250 \mathrm{msl}$ reported $249.72 \mathrm{~g} / \mathrm{m}^{2}$ (Pant and Lekhak, 2008). Similarly, the maximum biomass $(39.75 \mathrm{t} / \mathrm{ha}$ ) was found at $3650 \mathrm{msl}$ whereas the minimum biomass $(23.03 \mathrm{t} / \mathrm{ha})$ was found at $3450 \mathrm{msl}$ in upper Mustang rangeland (Maharjan, 2010) and 50- 1020 $\mathrm{g} / \mathrm{m}^{2}$ above ground biomass reported from the grassland of Annapurna Conservation Area in Manang district at $3500 \mathrm{msl}$ (Bhattarai et al, 2004).

Both aboveground biomass (AGB) and belowground biomass (BGB) of the Jaljale-Gorujure and Jaljale-Milke rangelands found to be significantly $(p<0.05)$ different, while performing analysis of variance (ANOVA).Further on performing Post-Hoc test of LSD test both AGB and BGB were found to be nonsignificantly $(\mathrm{p}>0.05)$ different in Gorujure and Milke (Tabs. 2, 3).

The high altitude rangeland (Jaljale) has high amount of aboveground biomass because as lesser number of grazing animals can access it compared to low altitude 
D.K. Limbu and M. Koirala /Our Nature (2011) 9:107-111

Table 1. Descriptive statistics of AGB and BGB of study sites.

\begin{tabular}{|c|c|c|c|c|c|c|c|}
\hline \multirow{2}{*}{ Sites (altitude m) } & \multirow{2}{*}{ No } & \multicolumn{3}{|c|}{ AGB (t/ha) } & \multicolumn{3}{|c|}{ BGB (t/ha) } \\
\hline & & Mean & SD & Range & Mean & SD & Range \\
\hline Milke (3000) & 5 & $0.62 \pm 0.104$ & 0.234 & $0.35-0.87$ & $22.314 \pm 2.66$ & 5.949 & $16.93-32.09$ \\
\hline Gorujure (3500) & 5 & $0.62 \pm 0.071$ & 0.159 & $0.48-0.82$ & $29.168 \pm 3.84$ & 8.606 & $19.74-43.01$ \\
\hline Jalajale (4000) & 5 & $1.02 \pm 0.139$ & 0.311 & $0.74-1.50$ & $41.620 \pm 0.92$ & 2.065 & $39.20-43.48$ \\
\hline
\end{tabular}

Table 2. Least Significant Difference (LSD) test for identification of the significant mean difference of aboveground biomass.

\begin{tabular}{llccc}
\hline Sites (altitude m) & Sites (altitude m) & Mean difference & Std. error & Significance \\
\hline Milke (3000) & Gorujure (3500) & 0.0024 & 0.153 & 0.988 \\
Milke (3000) & Jaljale (4000) & $0.3984\left(^{*}\right)$ & 0.153 & 0.024 \\
Jaljale (4000) & Gorujure (3500) & $0.3960\left(^{*}\right)$ & 0.153 & 0.024 \\
\hline
\end{tabular}

* The mean difference is significant at the 0.05 level.

Table 3. Least Significant Difference (LSD) test for identification of the significant mean difference of belowground biomass.

\begin{tabular}{llccc}
\hline Sites (altitude m) & Sites (altitude m) & Mean difference & Std. error & Significance \\
\hline Milke (3000) & Gorujure (3500) & 6.8540 & 3.894 & 0.104 \\
Milke (3000) & Jaljale (4000) & $19.3051\left(^{*}\right)$ & 3.894 & 0.000 \\
Jaljale (4000) & Gorujure (3500) & $12.4511\left(^{*}\right)$ & 3.894 & 0.008 \\
\hline
\end{tabular}

* The mean difference is significant at the 0.05 level

rangeland (Milke). Aboveground biomass was relatively found less than belowground biomass because high intensity of grazing in the study area. There were large number of monocot plant species in high altitude rangeland where in lower rangeland, it is very low. The rangeland area is predominated with monocot plants Carex sp. and Agrostis pilosula species. Thus, monocot plant forms profusely its root at upper layer of soil and contributes large belowground biomass on rangeland.

This study showed that plant density influenced the biomass of plant on rangeland. Further, monocot plant density play crucial role for biomass contribution of rangeland, table 4 depicted that density percentage of monocot plant revealed increasing order from low altitude, Milke (5966 plant $/ \mathrm{m}^{2}$ ), to high altitude rangeland, Jaljale (13844 plant $/ \mathrm{m}^{2}$ ).
Table 4. Density of plant at study sites.

\begin{tabular}{|c|c|c|c|}
\hline \multirow[t]{2}{*}{ SN } & \multirow[t]{2}{*}{ Sites (altitude m) } & \multicolumn{2}{|c|}{$\begin{array}{c}\text { Plant density } \\
\text { (Individual } / \mathbf{m}^{2} \text { ) }\end{array}$} \\
\hline & & Dicot & Monocot \\
\hline 1 & Jaljale (4000) & 1411 & 13844 \\
\hline 2 & Gorujure (3500) & 1688 & 7233 \\
\hline 3 & Milke (3000) & 3444 & 5966 \\
\hline
\end{tabular}

In conclusion, both the above ground and below ground biomass of forage on high altitude rangelands are in increasing order with elevation gradient; it influenced the composition of monocot and dicot plant vegetation on rangeland too.

\section{Acknowledgements}

I would like to thank Mr. J.B. Limbu and Mr. M. Wongdi Sherpa who accompanied me 10 days visit on Jaljale area for research work. Mr. Sherpa always inspired us to climb and stay at high altitude and very 
D.K. Limbu and M. Koirala/Our Nature (2011) 9:107-111

thankful for his accommodation management. One of the authors (D.K.) is grateful to the University Grants Commission, Nepal for the research fellowship.

\section{References}

Bhattarai, K. R., O. R. Vetaas and John A. Grytnes 2004. Relationship between plant species and Biomass in an Arid Sub-Alpine Grassland of the Central Himalayas, Nepal. Folia Geobotanica 39: 57-71,

Conant, R.T., K. Paustian and E.T. Eelliott 2001. Grassland management and conservation into Grassland: Effects on Soil carbon. Ecological Applications 11(2): 343-355.

Food and Agricultural Organisation of the United Nations 2004. FAO statistical databases. Available http://faostat.fao.org/site/395/default.aspx.

Koirala, M. 2002. Environmental determinants of the livelihood related food production system in a Mid-Himalayan landscape (Tinjure-Milke region), east Nepal. Jawaharlal Nehru University, New Delhi, India. (Ph.D. Thesis)

LMP 1993. Livestock master plan. The livestock sector, volume III, Asian Development Bank/ANZDECK /APROSC.

Maharjan, M. 2010. Soil carbon and nutrient status of rangeland in Upper Mustang. Institute of Forestry, Tibhuvan University, Pokhara, Nepal. (M.Sc. Thesis)

Misra, R. 1968, Ecology Work Book. Oxford \& IBH Publishing Co., New Delhi.

MOPE 2002. Land use in Nepal. Ministry of Population and Environment, Nepal.

Ojima, D.S., B.O. Dirks, E.P. Glenn, C.E. Owensby and J.O. Scurlock 1993. Assessment of C budget for grasslands and drylands of the world. Water, Air and Soil Pollution 70: 95-109.

Oli, K.P. 2002. An assessment of Tinjure, Milke and Jaljale (TMJ) area of eastern Nepal. Internal Document, IUCN, Nepal.

Pant, P.and H.D.Lekhak 2008. Species Richness and Biomass Relationship in Burned Sites of Imperata-saccharum Grassland in Suklaphata Wildlife Reserve, Nepal. Ecoprint 15: 23-27.

Rai, N.K. and M.B. Thapa 1993. Indigenous pasture management system in high altitude Nepal, A review. Report series no 22, HMG Ministry of Agriculture/Winrock International.

Schimel, D.S., W.J. Parton, T.G. Kittel, D.S. Ojima and C.V. Cole 1990. Grassland biogeochemistry: Links to atmospheric processes. Climatic Change 17: $13-25$.

Schlesinger, W.H. 1997. Biogeochemistry: An analysis of global change. New York: Academic Press.

Scurlock, J.M. and D.O. Hall 1998. The global carbon sink: A grassland perspective. Global Change Biology 4: 229-233.

Shrestha, K.B. 1997. Status of community forestry in Nepal. A paper presented at the seminar on Conserving Biodiversity in Nepal's Community Forests. National Biodiversity Action Plan Project, Ministry of Forest and Soil Conservation, HMGN, Kathmandu, Nepal.

Tulachan P.M. and A. Neupane 1999. Livestock in mixed farming systems of the Hindu Kush Himalayas trends and sustainability. Food and Agricultural Organization of the United Nations and International Centre for Integrated Mountain Development, Kathmandu, Nepal.

Yonzon, P.B. and J.T. Heinen (eds) 1997. Nepal's biodiversity and protected areas. The 1997 Protected Areas Management Workshop of the National Biodiversity Action Plan, Kathmandu, Nepal. 